\title{
CHANGES IN THE SERA LEVELS OF AMYLOID A PROTEIN IN THE COURSE OF INFLUENZA, CHICKENPOX AND INFECTIOUS MONONUCLEOSIS
}

\author{
Iliyan Todorov ${ }^{1}$, Yana Bocheva², Margarita Gospodinova ${ }^{1}$, Gergana Popcheva $^{2}$, \\ Yordan Yordanov ${ }^{3}$ \\ ${ }^{1}$ Department of Infectious Diseases, Parasitology and Dermatovenerology, \\ Faculty of Medicine, Medical University of Varna \\ ${ }^{2}$ Department of General Medicine and Clinical Laboratory, Faculty of Medicine, \\ Medical University of Varna \\ ${ }^{3}$ St. Nikolay Chudotvoretz Eye Clinic, Varna
}

\begin{abstract}
INTRODUCTION: Until now, there has been no routinely measured laboratory marker, which indicates acute inflammation from viral origin. According to some authors, the serum amyloid A (SAA) protein is of great importance in such circumstances.

AIM: The aim of this article is to establish the clinical significance of SAA as a potential laboratory marker for viral infections.

MATERIALS AND METHODS: Sera samples from 93 subjects with different viral infections, including influenza $(n=31)$, infectious mononucleosis $(n=31)$, and chickenpox $(n=31)$ were analyzed. Levels of SAA were prospectively measured by immunoturbidimetry, adapted on Olympus AU 400. Thirty healthy subjects were included in the control group.

RESULTS: In comparison with the control group, the levels of SAA were significantly higher, reaching a mean concentration of up to $180.80 \pm 199.87 \mathrm{mg} / \mathrm{L}$. During convalescence, the levels decreased dramatically achieving a level of up to $31.29 \pm 83.42 \mathrm{mg} / \mathrm{L}$. The highest concentrations were registered in the cases with different complications, such as secondary bacterial infections. In comparison with erythrocyte sedimentation rate (ESR), C-reactive protein (CRP), and leukocytes, SAA levels were statistically significant for minor inflammatory stimuli, such as viral infections are.

CONCLUSION: SAA increases significantly in the course of different viral infections, such as influenza, infectious mononucleosis, and chickenpox. Early normalization of its levels correlates with full recovery, lack of complications and auspicious prognosis of the disease.
\end{abstract}

Address for correspondence:

Keywords: serum amyloid $A$, virus, inflammation, acute phase response, immune

Iliyan Todorov

Faculty of Medicine

Medical University of Varna

55 Marin Drinov St

9002 Varna

e-mail: ilio_87@abv.bg

Received: February 14, 2019

Accepted: March 18, 2019 


\section{INTRODUCTION}

Changes in the different laboratory markers, which appear in the course of many infectious diseases, have a great importance for establishing the correct diagnosis, as well as for the developed complications and outcome of the disease (1). Nowadays, routinely measured are leukocytes, C-reactive protein (CRP), and erythrocyte sedimentation rate (ERS), which par excellence indicate bacterial infections, but they also react during many autoimmune disorders and neoplastic diseases (2). Viruses induce a weak synthesis of the mentioned markers. Until now, a laboratory indicator for a virus-caused disease has not existed. Some authors declare that the serum amyloid A (SAA) protein may be useful because its serum concentrations increase 1000 fold in the acute phase of infectious mononucleosis, measles, chickenpox, herpes zoster, hepatitis, and influenza $(3,4)$.

\section{AIM}

The aim of this article is to study SAA as a diagnostic marker for virus-caused inflammation. For the achievement of that aim, we analyzed changes in the sera concentrations of SAA in the course of some acute viral infections: 1) in comparison with healthy controls; 2) in comparison with leukocytes, CRP, and ESR; 3 ) in the relationship with the severity of the disease and present complications.

\section{MATERIALS AND METHODS}

The study group consisted of 93 patients admitted to the Department of Infectious Diseases, St. Marina University Hospital, Varna, Bulgaria with an acute onset of influenza $(\mathrm{n}=31)$, chickenpox $(\mathrm{n}=31)$, and infectious mononucleosis $(\mathrm{n}=31)$. The control group consisted of 30 healthy subjects. The including criteria are shown on Table 1. Etiologic diagnosis was made by ELISA assay, proving the specific IgM antibodies blood circulation. Two serum samples of $5 \mathrm{~mL}$ were obtained by the Vacutainer System from all subjects - on the day of admission, and $4.97 \pm 1.35$ days later. Blood was centrifuged at $3500 \mathrm{x}$ g for $10 \mathrm{~min}$ by HERAEUS, Kendro, Germany centrifuge. Sera samples were stored at $-20^{\circ} \mathrm{C}$ until analyzed. SAA and $\mathrm{CRP}$ were measured by immunoturbidimetric assays, adapted on Olympus AU400, AU400 Chemistry Analyzer. New automatic technology, Roller20PN, ALIFAX, for measuring of ESR was used. Reference ranges for all markers are shown on Table 2. ANOVA test and post hoc analysis were used for comparison

Table 1. Inclusion criteria for the subjects from the analyzed and the control group

\section{Analyzed Group}

1-60 years of age

Acute onset of influenza, chickenpox, and infectious mononucleosis, incl. severe and complicated forms

Lack of chronic non-infectious diseases, such as hypertonia, chronic obstructive pulmonary disease, diabetes mellitus, etc.

Vaccination done more than 30 day before the onset of the disease

Signed informed consent form

\section{Control Group}

1-60 years of age

Healthy persons without signs and symptoms of any infectious disease

People without chronic diseases

Vaccination done more than 30 day before present blood analysis

Signed informed consent form

Table 2. Reference ranges of analyzed laboratory markers

\begin{tabular}{l|c}
\hline Laboratory Marker & Reference Range \\
SAA & $0-10 \mathrm{mg} / \mathrm{L}$ \\
CRP & $0-6 \mathrm{mg} / \mathrm{L}$ \\
Leukocytes & $4-10 \times 10^{9} / \mathrm{L}$ \\
& Children up to $\mathbf{1 4}$ years of age: $2-34 \mathrm{~mm} / \mathrm{h}$ \\
ESR & Adults up to $\mathbf{5 0}$ years of age: men: $2-28 \mathrm{~mm} / \mathrm{h} ;$ women: $2-37 \mathrm{~mm} / \mathrm{h}$ \\
& Adults over $\mathbf{5 0}$ years of age: men: $2-37 \mathrm{~mm} / \mathrm{h} ;$ women: $2-39 \mathrm{~mm} / \mathrm{h}$ \\
& Adults over $\mathbf{7 0}$ years of age: $3-46 \mathrm{~mm} / \mathrm{h}$ \\
\hline
\end{tabular}


Iliyan Todorov, Yana Bocheva, Margarita Gospodinova et al.

between SAA and other studied markers for inflammation. Paired $t$-test was used for analyzing the role of SAA as a marker for severe and complicated form of infection. A p-value $<0.005$ was considered statistically significant.

\section{RESULTS AND DISCUSSION}

Ninety-three patients were analyzed in the present study. Two subgroups were formed: non-severe $(n=62$, or $66.67 \%)$ and severe, complicated $(n=31$, or 33.33\%). On the day of admission, $81(87.10 \%)$ patients' sera reacted with higher than normal SAA concentrations with rapid decline during the convalescent stage (see Table 3). This fact indicates that SAA may be used as a potential laboratory marker for acute onset of viral infections, and also, it has an early prognostic value about the outcome of the disease.

However, 34 (36.56\%) patients' sera samples stayed abnormal even throughout the convalescence. We think that this phenomenon results from a lack of full recovery at the time when the second sample was obtained. It suggests SAA could be a useful marker about the grade of recovery and it respectively determines the optimal duration of the initiated treatment.

The same results have been registered by Miwata et al. in 1993 (5) and Yueru et al. in 2017 (6), who have found that the levels of SAA were higher in the viral infection group than those in healthy controls and concluded that normal concentrations of SAA in the second sample correlated with the full recovery of the patients.

In addition to SAA, the levels of CRP, ESR, and leukocytes were determined in all subjects (see Table 4). SAA showed a greater incremental change in the acute phase, with concentrations ranging from 0.8 to $1041.0 \mathrm{mg} / \mathrm{L}$ when compared with CRP (0.17$402.87 \mathrm{mg} / \mathrm{L})$, ESR $(4-120 \mathrm{~mm} / \mathrm{h})$, and leukocytes $\left(2.25-31.26 \times 10^{9} / \mathrm{L}\right)$. High SAA concentrations were observed despite normal CRP, ESR, and leukocytes count in 24 (25.81\%), 40 (43.01\%), and 57 (61.29\%) subjects, respectively. It is known that the mentioned three laboratory markers do not react (or they react within narrow limits) in the course of a viral inflammation. So, our results are similar to those published by some authors, who indicate SAA is a sensitive acute phase protein, which increases during minor inflammatory stimuli induced by different viruses $(7,8,9)$.

Table 5 shows all the complications we registered in our patients.

Analyzing the severe, complicated group (31 subjects), we found that changes only in SAA concentrations were statistically significant to report a present complication ( $\mathrm{W}=4.89, \mathrm{p}=0.021)$. Such characteristic was mostly related with the cases of infectious mononucleosis and chickenpox, where $\mathrm{p}<0.028$. So, on the basis of the post hoc analysis (see Table 6), we did not find significant differences for ESR and CRP in subjects from all three studied infectious diseas-

Table 3. Mean concentrations of SAA $(\mathrm{mg} / \mathrm{L})$ in the acute and convalescent stages of the illness

\begin{tabular}{lc|c|c|c} 
& \multicolumn{4}{c}{ Viral Infections } \\
Stage of Illness & Infectious Mononucleosis & Influenza & Chickenpox & Controls \\
& $\mathrm{n}=31$ & $\mathrm{n}=31$ & $\mathrm{n}=31$ & $\mathrm{n}=30$ \\
Acute & $259.20 \pm 223.43$ & $168.92 \pm 229.34$ & $123.28 \pm 146.83$ & $3.08 \pm 1.93$ \\
Convalescent & $24.33 \pm 33.47$ & $52.11 \pm 174.87$ & $17.44 \pm 41.94$ & \\
\hline \hline
\end{tabular}

Table 4. Mean concentrations of ESR, CRP, and leukocytes in the acute and convalescent stages of the illness

\begin{tabular}{l|c|c|c|c|}
\hline Stage of Illness & Diagnosis & ESR & CRP & Leukocytes \\
\cline { 1 - 3 } Acute & Influenza & $34.48 \pm 24.17$ & $43.34 \pm 89.66$ & $7.21 \pm 3.45$ \\
& Chickenpox & $33.42 \pm 24.88$ & $20.33 \pm 22.63$ & $7.74 \pm 3.56$ \\
& Infectious mononucleosis & $42.77 \pm 24.06$ & $48.70 \pm 52.94$ & $11.62 \pm 5.17$ \\
Convalescent & Influenza & $29.81 \pm 22.98$ & $16.71 \pm 40.80$ & $6.49 \pm 2.69$ \\
& Chickenpox & $29.59 \pm 18.79$ & $3.46 \pm 4.28$ & $6.87 \pm 2.33$ \\
\hline \hline
\end{tabular}


Changes in the Sera Levels of Amyloid A Protein in the Course of Influenza, Chickenpox and Infectious Mononucleosis

Table 5. Complications registered in the studied subjects

\begin{tabular}{lcc} 
Complications & Numbers & $\%$ \\
Acute bronchitis & 13 & 41.9 \\
Acute laryngitis & 2 & 6.5 \\
Acute tonsillitis & 2 & 6.5 \\
Acute pyelonephritis & 1 & 3.2 \\
Pneumonia & 3 & 9.7 \\
Herpes simplex labialis & 1 & 3.2 \\
Mixed infection with rotavirus & 2 & 6.5 \\
Acute hepatic involvement & 5 & 16.1 \\
Furunculosis & 1 & 3.2 \\
Nephrotic syndrome & 1 & 3.2 \\
Total & $\mathbf{3 1}$ & $\mathbf{1 0 0 . 0}$ \\
\hline
\end{tabular}

Table 6. ANOVA test

\begin{tabular}{lccc}
\hline & & & p-value \\
\multirow{2}{*}{ SAA } & Welch & $\mathbf{4 . 8 9 7}$ & $\mathbf{0 . 0 2 1}$ \\
& Brown-Forsythe & $\mathbf{4 . 3 3 3}$ & $\mathbf{0 . 0 2 7}$ \\
ESR & Welch & 0.006 & 0.994 \\
& Brown-Forsythe & 0.005 & 0.995 \\
CRP & Welch & 3.434 & 0.058 \\
& Brown-Forsythe & 1.083 & 0.359 \\
\multirow{2}{*}{ Leukocytes } & Welch & 3.448 & 0.065 \\
& Brown-Forsythe & 2.508 & 0.120 \\
\hline
\end{tabular}

es, which is opposite to the literature data about the great potential of CRP as a laboratory marker for secondary bacterial infections $(10,11)$.

\section{CONCLUSION}

In conclusion, we establish that SAA may be used as a sensitive laboratory marker for early diagnosis of different viral infections. It is more sensitive than CRP, ESR, and leukocytes. Also, its rapid decrease indicates convalescent stage, which indirectly correlates with the optimal duration of the treatment and early and exact prognosis about the disease outcome. Compared with other acute phase proteins, SAA is more sensitive as a marker for present complications, especially in the course of infectious mononucleosis and chickenpox. So, we recommend routine measurement of SAA in the clinical practice of medical doctors who work with patients suffering from viral infections.

\section{REFERENCES}

1. Genev G, Popova M. Klinichna stoinost na savremennite izsledvaniya v infektologiyata. Plovdiv, Bulgaria: Meditsinsko izdatelstvo Raikov; 2006. (in Bulgarian).

2. Peter J. Use and interpretation of laboratory tests in infectious diseases. 6th Edition. Specialty Laboratories; 2000.

3. Lannergard A, Larsson A, Kragsbjerg P, Friman G. Correlations between serum amyloid A protein and C-reactive protein in infectious diseases. Scand J Clin Lab Invest. 2003; 63(4):267 - 72.

4. Shainkin-Kestenbaum R, Zimlichman $\mathrm{S}$, WinikoffY, Pras M. Chaimovits C, Sarov I. Serum amyloid A (SAA) in viral infection: rubella, measles and subacute sclerosing panencephalitis (SSPE). Clin Exp Immunol. 1982;50(3):503-6.

5. Miwata H, Yamada T, Okada M, Kudo T, Kimura $\mathrm{H}$, Morishima T. Serum amyloid A protein in acute viral infections. Arch Dis Child. 1993;68(2):210-4.

6. Tian Y, Li W, Ye Z. Determinations of serum amyloid A and C-reactive protein for the diagnosis of infectious diseases in children[J]. Laboratory Med. 2017;32(5):382-5.

7. Nakayama T, Sonoda S, Urano T, Yamada T, Okada $\mathrm{M}$, Monitoring both serum amyloid A protein and C-reactive protein as inflammatory markers in infectious diseases. Clin Chem. 1993;39(2):293-7.

8. Niemi K. Serum amyloid A (SAA): proinflammatory functions and their regulation by serum lipoproteins. Academic dissertation. Helsinki;2012.

9. Salini V, Saggini A, Maccauro G, Caraffa A, ShaikDasthagirisaheb YB, Conti P. Inflammatory markers: serum amyloid A, fibrinogen and C-reactive protein - a revisited study. Eur J Inflamm. 2011;9(2):95-102.

10. Falsey A, Walsh E, Francis C, Looney R, Kolassa J, Hall W, et al. Response of C-reactive protein and serum amyloid a to influenza a infection in older adults. J Infect Dis. 2001;183(7):995-9.

11. Yamada T. Inflammatory markers; $\mathrm{C}$-reactive protein (CRP) and serum amyloid A (SAA). Rinsho Byori. 2005;53(6):558-61. 